\title{
EMERGENT GLOBAL LAND GOVERNANCE
}

\author{
Matias E. Margulis* \\ Division of History and Politics \\ University of Stirling \\ Email: m.e.margulis@stir.ac.uk
}

\begin{abstract}
Land governance is currently the focus of many new global rule-making projects, marking a sharp break with past practices that sought to exclude land as an international governance issue. Wideranging concerns about land grabbing and its exclusionary and ecological consequences have driven this, prompting states and global civil society to devise new global land-governance instruments. This chapter offers a preliminary theoretical and empirical analysis of what is conceptualized as “emergent global land governance," focusing primarily on its international governance dimensions. A review of relevant land-governance policy instruments in the fields of investment, land tenure, and forestry suggests that emergent global land governance is likely to consist of multiple, overlapping instruments with diverging normative frameworks and objectives that are not closely coordinated instead of a singular, discrete international regime.

*This is an Accepted Manuscript of a chapter published in Karen C. Seto \& Anette Reenberg (eds.), Rethinking Global Land Use in an Urban Era (Cambridge: MIT Press): 183-200. More information available at: https://mitpress.mit.edu/index.php?q=books/rethinking-global-land-use-urban-era
\end{abstract}




\section{Introduction}

Land now occupies a significantly higher profile in global governance deliberations compared to past decades. The principle reason for this renewed interest in land and its governance at the globalscale is the recent wave of large-scale acquisitions of agricultural land (itself part of the broader global phenomenon of 'land grabbing'). Land governance is currently the subject of new global rule-making projects at international organizations such as the Food and Agriculture and Organization (FAO) of the United Nations (UN), the World Bank and the Group of Eight (G8)/Group of Twenty (G-20), which are clubs of states with the largest economies. Ongoing work to establish global rules to regulate foreign investment in agricultural land is a major element of transnational advocacy by prominent international non-governmental organizations (INGOs) such as Oxfam, and global social movements, such as the food sovereignty movement. Private actors too, including transnational agri-food corporations and institutional investors, have also expressed an interest in global rules to ensure their current and future investments in land are coherent with best practices on socially responsible and sustainable investment, as well as in order to minimize risk to their profits and reputation. These developments confirm a rising interest in and demand for global forms of land governance.

The current flurry of activity surrounding global rule-making for land makes a compelling case for greater scholarly analysis of new developments in land governance. In addition, land also provides an important case for the study of contemporary global governance practices given that land has hitherto been treated as a local/national policy issue rather than one of global concern. This chapter offers a preliminary theoretical discussion and empirical analysis of what can be described as emergent global land governance, that is, the set of norms, rules, institutions and practices shaping contemporary governance of land at the global-scale. The focus herein is on international/public modes of global governance since much of the new global rule-making projects are primarily taking place in traditional international organizations such as the FAO. However, the role of nonstate/private modes global governance relevant to land, and their overlap with international/public ones, is acknowledged as important but is treated elsewhere in this collection (see Gentry et al. 2013; Borras et al 2013c; Auld 2013). At the same time it is important to note that the distinction between international/public and transnational/private is ever more blurred with global civil society and private actors ever more engaged in policymaking at traditional intergovernmental bodies such as the UN Committee on World Food Security, even though formal decision-making remains the exclusive prerogative of nation-states. ${ }^{i}$ The chapter is organized as follows. The first section situates the rising interest in land governance and demand for global-scale forms of land regulation as a response to the contemporary phenomenon of 'land grabbing'. The second section elaborates on the concept of emergent global land governance in reference to contemporary debates about global. The third section identifies key institutional elements of emerging global land governance through a comparison of governance instruments across the fields of investment, food and agriculture, and forestry and discusses the key trends in this governance field. The last section concludes with a discussion of the longer-term policy and political challenges in emergent global land governance.

\section{Rising Interest in Land and Demand for Global Governance}

Land governance is by no means a new area of policy debate and the challenges of land governance are part of the everyday politics in many jurisdictions, for example, such as land redistribution to landless peasants in Brazil or reclassifying farmland for conservation purposes in the United States. Since 2008 there has been heightened interest in land and its governance because of a massive wave of 'land grabbing' worldwide. Contemporary land grabbing has significantly altered the political 
dynamics, discourse and goals of land governance debates in response to the policy and ethical challenges posed by land competition in ever more teleconnected world.

\section{'Land Grabbing' As Context}

The recent wave of land grabbing has galvanized international attention and energy to the issue of land governance in an unprecedented manner. The land grabbing phenomenon first came to global attention in the summer of 2008 following a report by the Spain-based NGO GRAIN that documented a sharp increase in the sale or lease of very large units of agricultural land in developing countries by foreign investors and governments (GRAIN 2008). Subsequent research by academics and international organizations has confirmed land grabbing as an extensive international phenomenon (Cotula et al. 2009; World Bank 2009; GTZ 2009; Friis and Reenberg, 2010; Deininger et al, 2011; Anseeuw et al. 2012a:2012b; Oxfam 2012; Cotula 2011:2012).

Six key characteristic are briefly highlighted to contextualize the unique features of contemporary land grabbing and why land grabbing has become such a prominent issue of global concern. First, the global land grab is a recent phenomenon. It is well established that land grabbing proliferated during and after the 2008 'triple' food-fuel-financial crisis. Whereas some land grabbing was taking place prior to the 2008 crises, this was relatively marginal, and the trend line spiked sharply in 2008. Table 1 (see below) provides an illustration of this trend drawing on recent data reported by the Land Matrix Project that is the best available source at present. ${ }^{\mathrm{ii}}$ The unique timing of the sharp rise in land grabbing supports numerous theories that regard contemporary land grabbing as driven by the attractiveness of rising returns in the agricultural sector and in farmland values, growing international demand for biofuels, and strategies for securing agricultural supplies by nations and corporations (Cotula et al. 2009; World Bank 2009; Borras et al. 2010). Second, the scale of contemporary land grabs has been of a significant magnitude. Estimates range between 50 million hectares (World Bank 2009) and 227 million hectares (Oxfam 2012) of farmland that has been grabbed. It is generally acknowledged that complete data remains patchy due both to the lack of transparency of most land deals, the lack of agreed upon methods (Cotula 2012), and the politics of numbers at play in global policy debates given the centrality of numbers to informing actors' identities and preferences (Margulis, McKeon and Borras 2013). Despite these tensions about the data, all the estimates clearly point to a substantial figure.

Table 1: Land Grabs by Hectares and Number Deals, 2006-2011

\begin{tabular}{|l|l|l|}
\hline Year & Hectares & Number of Deals \\
\hline 2006 & 450,640 & 43 \\
\hline 2007 & $1,123,275$ & 29 \\
\hline 2008 & $1,723,457$ & 36 \\
\hline 2009 & $1,879,108$ & 39 \\
\hline 2010 & $1,303,609$ & 23 \\
\hline 2011 & 422,200 & 3 \\
\hline Unaccounted & $44,234,183$ & 738 \\
\hline
\end{tabular}

Source: Land Matrix (http://landportal.info/landmatrix/get-the-detail/by-year)

Third, land grabbing is occurring in all regions of the world make it a global-scale phenomena. Sub-Saharan Africa is certainly a hot spot for land grabs but recent research has also shown intensifying land grabbing activity in Asia (Hall 2011), Eastern Europe (Visser and Spoor 2011), the Americas (Borras et al. 2013b) and Oceania (Filer 2012). There is growing evidence of land grabbing expanding into the North with Australia so far a major site of foreign investment in farmland. Fourth, the source of investors in farmland is highly diverse and extends beyond actors traditionally engaged in agriculture, including states (including sovereign wealth funds) and a range of private sector actors (e.g., agri-food corporations, commodities traders, and institutional investors) located in the North and Global South (Margulis and Porter 2013; Daniel 2012). Fifth, the available data suggests that a significant proportion of land grabbing has been to produce 'flex 
crops and commodities’ (Borras, Franco and Wang, 2013; Anseeuw et al. 2012b: xi) such as palm, soy and sugar that are important to the expanding global biofuel complex. This suggests that demand for biofuels, and the policies stimulating their greater use in transport fuels, have turned out to be much more significant drivers of land grabbing than initially projected when land grabbing was largely predicted to be for the outsourcing of food (Robertson and Pinstrup-Andersen 2010). Sixth, land grabbing is associated with the interaction among land and new and diverse sets of technologies - such as new seeds and genetic materials and high-tech production technologies (i.e., automated mega-farms controlled by distal headquarters); new financial products such 'land funds' enabled through digitized trading and speculation in financial markets; and new means of 'discovering', measuring and mapping land with geographical information's systems (GIS). For example, GIS makes it possible to identify 'available' lands and facilitate land deals from a virtual distance; deals can take place without buyers and sellers ever meeting or coming together physically on site.

Land grabbing is one of many terms that refers to the large-scale acquisitions of land for the purpose of outsourcing of agricultural production. There is no consensus definition and therefore a significant scholarly (and real world political) debate about what is and is not land grabbing (see Margulis, McKeon and Borras 2013). Rather than repeat that debate here, this chapter takes as a starting point Borras et al.'s (2012, p.405) approach that situates land grabbing as one manifestation of control grabbing that is defined as:

"[T]he capturing of control of relatively vast tracts of land and other natural resources through a variety of mechanisms and forms involving large-scale capital that often shifts resource use to that of extraction, whether for international or domestic purposes, as capital's response to the convergence of food, energy and financial crises, climate change mitigation imperatives and demands for resources from newer hubs of global capital.”

This is an analytically useful definition of land grabbing because it is does not overemphasize the quantitative dimension of land grabbing (however, scale and measurement remain important). This definition provides a framework that captures the potential diversity of localized forms of land grabbing, such as 'green grabs' (Fairhead et al. 2012), 'water grabs' (Metha et al. 2012; Allan et al. 2012) and other forms of the 'foreignization' of space (Zoomers 2010). In addition, the idea of control grabbing captures that contemporary land grabbing is driven by changes in the global political economy, including the decision by distal agents to (re)valorize foreign land as an important economic commodity, which in turn, is leading to what the globalization theorist Saskia Sassen (2013) argues is a nascent global land market.

Contemporary land grabbing echoes the great land rush during the era of imperialism and colonialism. In turn, this had prompted a scholarly debate the similarities and differences between land grabbing today and in the past (Alden-Wily 2012; Ayers 2013). Depending on the theoretical framework and time-scale used, scholars draw different conclusions on what is novel about contemporary land grabbing and to what extent is a continuation of historical patterns of capitalist world development. Post-colonial and imperial frameworks are useful because they shed light on how past (and contemporary) asymmetries in power among agents and local populations shape societal conditions, which in turn drive land use decisions. Yet the six characteristics discussed above highlight the importance of factors that do not fit well with neo-imperial and -colonial frameworks because land grabs today differ in two key respects. First, contemporary land grabbing involve a much more diverse set of actors, institutions and governance practices that did not exist during the era of colonialism and imperialism (Margulis and Porter 2013). Second, many land grabs do match well earlier patterns of core-periphery and North-South relations; polycentrism is a major feature of contemporary land grabbing as is the prominence of 'land grabbed land grabbers' such as Brazil (Borras et al 2013b; Rulli et al 2012). 


\section{Demand for Global Land Governance}

Demand for global governance of land in response to the speed, scale and extensiveness of land grabbing can be argued to be driven by two categories of concerns. For the purpose of the analysis here these two categories are treated as ideal types. These two categories of concerns are important because they serve as the organizing frameworks for much of the transnational advocacy on land grabbing that has been instrumental in framing the demands for new and robust forms of global land governance and continue to inform the global political contests over future global land governance. ${ }^{\text {iii }}$

The first category fall under the label of exclusion and this refers to situations where communities and individuals are displaced by land grabs. Exclusion can occur in legal, peaceful and voluntary ways but also in illegal, violent and coercive ways. This concern is principally an ethical/social justice framing. The principal problem here is that certain communities - small scale farmers, agricultural workers, indigenous peoples, and other vulnerable and marginalized peoples - are more likely experience a loss of livelihoods, violence, and be excluded from socially and economically valuable lands and resources. The actual forms of exclusion will very significantly given factors such as population density, the type of land tenure arrangements in place, the type of agricultural practices, and the crop in question, and so on. But the basic point is that most people who continue to live on the land are among the most poor and face few, if any, alternative economic opportunities. For many individuals the loss of or diminished access to land can become a matter of personal survival.

The most visible expression of concerns over exclusion has come from global civil society, including the 2011 "Stop the Land Grab" campaign led by the transnational peasant movement, $L a$ Via Campesina, which has emphasized the importance of international public regulation and proposed an international moratorium on land grabbing and to make states and investors accountable. In 2012, well known INGOs such as Oxfam and ActionAid called for a moratorium on land grabs in Africa. Oxfam, for example, has made land grabs a key theme of their new high profile international agriculture and food focused campaign, GROW calling for international good governance standards for land deals to prevent the displacement and further impoverishment of vulnerable people. Global campaigns organized around the idea of exclusion prioritize protecting the land tenure of vulnerable groups. This has also included documenting cases of exclusion and bringing such cases to the attention of global publics and international bodies (Graham et al. 2010).

There is a related geopolitical and geoeconomic concern that falls under the exclusion label. This concern emphasizes the potential for escalating social conflict and economic risk arising from tensions between locals and land grabbers (e.g., access to land and resources, effects on land prices), citizens and their governments (e.g., political contestation over land deals, corruption and legitimacy of 'complicit' governments, food insecurity), and among states contesting the legitimacy of land deals and their effects on commodity markets. Geopolitical and geoeconomic concerns have loomed larger at inter-state forums, such as the Group of Eight (G-8) summit in L'Aquila and the UN where debates about land grabs were framed in terms of political instability in host states, especially after the fall of the Madagascar government in 2008 following a significant land deal there.

The second set of concerns fall under the label of ecological risk. This refers to concerns about the potential negative environmental consequences of land grabs. Such effects can occur in a myriad of ways such as environmental damage caused by the intensification of extractive forms of production or the loss of biodiversity and traditional knowledge when industrial mono-cropping for biofuels supplants more traditional forms of agriculture. It is only recently that agriculture has figured more 
seriously in climate change science even though it has long been well known that agricultural production is the single largest use for land (Turner et al. 2007). A recent study by the Washingtonbased International Food Policy Research Institute (Nelson et al. 2010) calculates that agricultural emissions account for almost one-third of greenhouse gas (GHG) emissions globally, a number significantly greater than estimates just a few short years ago and which is more than the energy and transport sectors combined. The available data suggests that much land grabbing has been for the industrial production of agriculture commodities for global biofuel and meat production (Anseeuw et al. 2012a), both of which are carbon-intensive activities and associated with net increases GHG emissions. Therefore, land grabbing is a concern if it encourages the expansion of carbon-intensive modes of agricultural production.

There teleconnected driven ecological tensions in the case of land grabbing when policies intended to promote positive environmental outcomes in one jurisdiction can have negative environmental effects in another. The most well-known is the case of corn and palm-based biofuels that is a significant driver of land grabbing and has spatially dispersed social and environmental effects when 'green energy' is produced in country but consumed in another (Wicke 2013; van der Horst and Vermeylen 2011). Another significant concern of ecological risk is that land grabbing may exacerbate the vicious cycle tension of carbon-intensive agricultural practices and degradation of ecological resilience in light off the general vulnerability of agriculture yields to climatic changes. From this standpoint, land grabbing of farmland is at odds with the scientific consensus on the need to shift towards low-carbon forms of agriculture and sustainable intensification (see Fen and Ramirez 2012).

Ecological risk concerns are evident in the work of major INGOs, including Action Aid's campaign on land grabbing that calls for reform of the EU's biofuel policy, Friend of the Earth International's (FOEI) critiquing the World Bank's involvement in supporting land grabs to set up oil palm plantations in Uganda, and Green Peace's 2011 blockade of land grab-related timber exports in Papua New Guinea. In general, these campaigns have sought to frame land grabs as a threat to sustainable development. The work of the FOEI, for example, has also attempted to highlight the World Bank's facilitating of land grabs and in turn called for reform of the multilaterals' policy that 'aid and abets' land grabbing. These concerns are also evident in the manner in which agriculture has taken on greater importance in the international climate change talks since 2009.

In reality concerns about exclusion and ecological risk overlap considerably. However in the everyday real world debates about global land governance the two categories remain disconnected. The International Land Coalition's Madiado Niasse (2011, p.1) argues the debates about land governance "is typically ignorant of and disconnected from the discourse on the physical condition of the land, despite the fact that the latter affects the productive capacity of the land". Similarly, the land use science has disconnected land from its socio-economic relations. Bridging this divide is an objective of this volume (see Seto and Reenberg 2013) and the concept of telecoupled systems (Liu and Hull 2013) is helpful in this regard by providing a conceptual framework and language to describe what are highly complex human-land interactions. However, the disconnection between concerns about exclusion and ecological risks in everyday politics are not only a result of a lack of knowledge or communication. Many political actors are aware of these linkages, however, many within the exclusion camp must strategically engage with dealing with human indignities in the here and now. Ecological risks, and land use science, operates on much longer time horizons that cannot easily always be framed into immediate political action. But going forward the prospects for bridging the disconnect between concerns about exclusion and ecological risk in contemporary global land governance debates are likely to improve as both the knowledge of telecoupled systems advances and is translated to policy actors, and with repeated interaction among actors engaged in articulating these concerns in global policy spaces becomes more frequent. 


\section{Emergent Global Land Governance}

Rising concerns about land grabbing and actions to address these are producing emergent global land governance. To date, the issues of land tenure and investment have appeared to gain the most traction. This development is captured by two recent global governance instruments: the UN Voluntary Guidelines for Responsible Governance of Land, Fisheries and Forests in the Context of National Food Security and; ongoing negotiations for principles on responsible agriculture investment. These instruments might be said to fall more closely under the concerns captured by the exclusion label. By comparison, the ecological dimension appears to be less prominent in emergent global land governance.

Before plunging headlong into the analysis of the constituent parts of emergent global land governance, I now turn to a discussion of global governance. The purpose is twofold; to clarify the concept of global governance and situate land as a global governance issue.

\section{Global Governance}

Global governance is term that is widely used to refer to the modern practice of governing transborder problems and to the institutions, rules, and actors that govern the global political economy. Global governance as an academic concept and field emerged in the 1990s in response to new global-scale problems such as HIV/AIDs, climate change and migration that were beyond the capacity of any single nation-states to manage on their own (Roseneau 1995). The field of global governance was also deeply influenced by shifting power at the global level such as the fall of Soviet Union and what this meant for US unipolarity and multilateralism. More recent work has focused on emerging countries as new powers in multilateralism. In addition to this state-centric work, other research into power in global governance has highlighted the shift to non-state forms of authority with transnational business and global civil society increasingly taking on greater roles and influence in global governance institutions.

Several concepts from global governance scholarship are relevant for the study of land as a global governance issue. The first is the concept of authority that is closely related to the idea of governance; which actors have authority to regulate a particular sphere of activity? Global governance scholarship has shown that authority has flowed into two principles ways over the past decades in ways that differ from the immediate post-war era; a shift of authority from the state to international institutions that have the capacity to constrain state sovereignty (e.g., European Union (EU), World Trade Organization (WTO) and International Criminal Court (ICC)), and a shift of authority to non-state actors that have taken on governance functions in existing policy fields but also in new areas of activity. The latter includes private actors, for example, such as credit rating agencies that have a significant influence on the state's financial affairs to industry associations that create standards for self-regulation to private international arbitration of financial and investment deals (Cutler et al 1999). This also includes global civil society organizations (Smith 2007), for example, engaged in fair trade labeling and certification or developing standards for humanitarian assistance. These developments also confirm another important trend in global governance; the proliferation of new, diverse forms of global governance in addition to those associated with traditional inter-state bargaining.

Scholars have described the present state of global governance as thick and dense because of the proliferation of public and private global governance instruments (Raustalia and Victor 2004). The increasing density of global governance is important in two ways. First, it points to a significant change in the "architecture" of global governance. Much of the post-war system international governance was founded on narrowly focused instruments to address what were perceived as discrete issue areas such as security, finance and trade. Global governance today looks somewhat 
different; issue areas are no longer governed by singular instruments but often by multiple, overlapping instruments. Take, for example, intellectual property rights that are governed by the 1994 Trade-Related Aspects of Intellectual Property Rights Agreement (TRIPS) under the WTO and various standards negotiated by states at the World Intellectual Property Organization (WIPO). This trend towards greater plurality of instruments in global governance is partially explained by a greater awareness of, and acceptance by, policymakers and other policy actors that most governance challenges are multidimensional and complex and that these require accordingly more extensive and flexible forms of governance. This is evident in various fields, such as efforts to fill the gaps in governance when it comes to trade and the environment or security and migration. Multiple instruments that cut across issues area also arise when states and non-state actors engage in strategic and tactical approaches to global governance that assemble existing and new instruments into novel configurations (Young 2002; Raustalia and Victor 2004). The motives for this can vary highly, ranging from a desire to simplify and streamline governance; increase policy coherence, and; reshape governance arrangements to make them more favorable to the interests of powerful or weaker actors.

\section{Land as a Global Governance Issue}

Land has not traditionally been understood as a global-scale "problem" like other fields of global governance such as climate change, HIV/AIDs, and terrorism. There are several intellectual and political reasons for this state of affairs. The foundations of the present international system are premised on the territorial sovereignty of the nation state and of which land control is a defining feature; this is affirmed by practices such as international legal recognition of state borders and authority of nation-states to govern as they wish within their demarcated territory. In addition, politics and ideological struggles during the Cold War in particular kept land reform out of international deliberations and instead framed them as bilateral development issues (Margulis, McKeon and Borras 2013).

The current situation is distinct - states and non-state actors treat land as a global issue that requires global-scale forms of governance. This is primarily the case because today policymakers understand that land is teleconnected and telecoupled. Ever greater transborder flows of ideas, capital, and technology, and transboundary challenges such as climate change, are driving substantive shifts in land use change and the distribution and access to the bundle of resources (soil, water, genetic material and sub-soil minerals, etc.) that constitute 'land' for those who live directly and indirectly off the land. However, land as sovereign territory and as a commodity are two powerful paradigms highly visible in these new global politics. Yet these are not the only land-related paradigms of importance. The discourse on the use of land for environmental services under the climate change regime has gained significant traction although its presence in new international rules is yet to be codified it remains problematic (Norgaard 2010). We also see an unfolding struggle to create new international rights such as the right of indigenous people and peasants to land (Jones 2011; Xanthaki 2010). The multidimensionality of land and the increasing plurality of relevant governance institutions and practices (mostly at the global level) suggest that land will less likely be a coherent, singular issue area. Instead, aspects of land governance appear to cut across various scales and issue areas.

\section{Constituent Elements of Emergent Global Land Governance}

This section provides an initial mapping of the constituent elements of the current embryonic stage of global land governance. Three constituent elements are selected - investment, land tenure and forestry - because they are specific to global land governance or highly relevant to it. Of course many other relevant instruments exist related to conservation (i.e., payment for ecosystem services, transfronteir conservation areas, etc.), Convention No. 169 of the International Labor Organization 
(ILO) on the rights of indigenous and tribal peoples, and so on but these are not addressed here. Indeed, the three elements discussed below are illustrative and not meant be comprehensive.

\section{Investment}

Foreign investment by states, transnational corporations, institutional investors, and domestic elites in land has been the principal mode of land acquisition during the contemporary land grab. Investment in land raises several concerns, ranging from the lack of prior and informed consent of local communities whose land is sold or leased to the risks for investors active in states with weak regulatory regimes and where land deals may be revoked if the political climate changes.

Investment in land for agriculture is a sphere of activity that has elicited the creation of a new global governance framework for land. In 2009, the G-8 agreed to "work with partner countries and international organizations to develop a joint proposal on principles and best practices for international agricultural investment" iv "The first development was the consultations for the socalled Principles on Responsible Agriculture Investment (PRAI) that was led by the World Bank in partnership with FAO, UN Conference on Trade and Development (UNCTAD), and the Organization for Economic Cooperation and Development (OECD). A first draft of the principles was presented in 2010 after initial expert consultation among international officials and experts. ${ }^{\mathrm{V}}$ The G-8 and G-20 have repeatedly affirmed their support for the PRAI, most recently at the 2012 Camp David and Los Cabos summits. However, many developed countries and global civil society refused to endorse the PRAI citing it had been developed without sufficient consultation and participation. As a result, in late 2012 states agreed to reopen the negotiation on responsible agricultural investment at the UN Committee on World Food Security (CFS). This process is to be completed by 2014 .

From the onset, the idea of responsible agriculture investment has been to establish a set of standards for private, foreign investment in agriculture that would encourage investment in that sector and minimize negative social consequences. General objectives include standards for free, prior and informed consent prior to the transfer of land, fair compensation of existing land users, and maximizing economic opportunities and protecting food security for local communities. The authors of the PRAI built upon various international standards and best practices relevant to investment in agriculture (and investment more generally) but that is tailored specifically to address the concerns associated with contemporary land grabs with an emphasis on transparency and sustainability. An international code of conduct for investors is seen by global policymakers as critical to maintaining the political consensus on increasing investment in developing countries' agriculture (Margulis and Porter 2013). For example, the G-8 and G-20 combined have pledged \$US 20 billion for multi-donor agriculture and food trust fund, the G8 recently established the \$US 3 billion 'New Alliance for Food Security and Nutrition, and the Gates Foundation and other philanthropic actors have donated hundreds of millions to support agriculture production in the Global South.

The effectiveness of responsible agricultural investment hangs on the assumption that increasing transparency and establishing criteria for best practices will lessen investment-related risks and increase the benefits of private investment in agriculture. This assumption draws on the success of other sectorial initiatives but especially the Extractive Industries Transparency Initiative (EITI) of which the World Bank is a major supporter. However, there are serious questions about the applicability of the EITI to agriculture because the range of investors and producers is far more diverse than in extractive industries and land grabbing is highly variegated with respect to the range the commodity being produced (i.e., food, feed, biofuels and other industrial inputs), the methods of production, end use, and final market destinations. Another important consideration is that EITI is mainly concerned with corruption and monitoring payments by firms to governments. Corruption and 'weak' governance in host states are a consideration in land grabbing but by no means the most 
important policy issue identified by actors. Therefore, it is not clear that the emphasis on corruption built into the EITI model translate all that well onto land grabbing and will address the problems of exclusion and ecological risk that frame the current debate and drive demands for global land governance.

The politics of responsible investment in agriculture are highly contentious. The legitimacy of this element of global land governance has been under a microscope because of the fact the initial principles were developed by international organizations with the support of G-8 instead of a universal body such as the UN and also because it was a top-down expert led exercise that had little direct participation by the private sector. Whereas much of global civil society was initially opposed to the PRAI, the decision to restart negotiation on principles at the CFS ensures that global civil society along with the private sector will work alongside states and international organizations to devise new standards for investment in agriculture.

\section{Land Tenure}

The Voluntary Guidelines for Responsible Governance of Land, Fisheries and Forests in the Context of National Food Security (from here in referred to as the 'VGs'), which were adopted in May 2012 at the FAO, is the instrument most associated in contemporary popular discourse and transnational advocacy with resect to global land governance. The VGs is a non-binding international document that provides a policy framework to enhance the tenure and access to land and productive resources by poor rural households. Livelihoods and preventing political, social and economic exclusion looms large in this document.

However, unlike responsible agricultural investment, international cooperation for creating the VGs preceded contemporary concerns about land grabbing. The impetus for VGs can be traced back to the 2006 UN International Conference on Agrarian Reform and Rural Development (ICARRD) during which states and global civil society organizations called for a global framework to implement enhanced land tenure at the national level. Indeed, many of the actors (e.g., developing countries and transnational peasant movements) involved in the VG negotiations regard the guidelines as a continuation of the ICARRD process.

It is clear that contemporary concerns about land grabbing have significantly influenced the VG negotiations and its outcome. One can go as far as to claim they put the negotiations on a new track and changed actors' perceptions of the importance of establishing the VGs. The official negotiation process of the VGs took place during 2010 and 2011. By this point, land grabs were a prominent issue and concerns about land grabbing appeared at the VG negotiations. The zero draft (i.e., first draft of negotiated text) of the VGs contained several proposals specific to addressing concerns about investment and large-scale land acquisitions. States and global civil society actors that negotiated the VGs confirm that land grabs was the most contentious issue in the negotiation (Seufert 2013). The final version of the VGs does not make direct reference to land grabbing nut instead refers to large-scale transactions (FAO 2011; FAO 2012), which is understood to refer to land grabs but used in the official text on the count that many parties to the negotiation were not comfortable with the term land grabbing viewed by some as 'too political' and others too vague for the specificity required in an international legal document.

The aim of the VGs, through its best practices-based approach, is to improve domestic governance of land tenure. This is logical given that land reform is an endemic, and often unresolved, political issue in many developing countries. Despite the emphasis on the national level there is much more to the VGs. First, the VGs expand their scope to include not just the national governments of states where land tenure issues are concerned; the guidelines also include provisions specific to private actors and transnational corporations, including obligations for the home states' of these actors to prevent abuses of land tenure and human rights. In addition, the VGs spell out the responsibilities 
for states involved directly (think China, Gulf States, etc.) in large-scale land acquisitions to ensure such investments are consistent with the protection of legitimate tenure rights, the promotion of food security and their existing obligations under national and international law (FAO 2012, p. 20). The VGs have also created a political space for transnational forms of implementation and monitoring of land tenure practices. One option currently being discussed is creating a monitoring mechanism under the auspice of the FAO's Committee for World Food Security and includes the participation of state and non-state actors. Such a mechanism, if achieved, would potentially strengthen land tenure by providing a forum for affected parties, especially marginal groups, to bring their concerns directly to the international community (similar to the special procedures of the UN Human Rights Council that allows parties who have had their human rights violated to seek international justice when national institutions are unable or unwilling to address such concerns).

\section{Forests}

The global governance of forests is highly relevant for emergent global land governance because of the direct link between land grabbing for palm-based biofuels, land grabbing for pulp, timber and/or bioenergy production inputs, and other 'green grabs' for conservation and carbon offset purposes. Up to now international forest governance has not figured prominently in the global land grab debate but is expected with new environmental governance instruments such as REDD+ argued to be a potential important driver for land grabbing in the future. In addition, forest governance is ever more relevant to land tenure issues now that the VGs explicitly apply to forests that in turn more closely links these two elements more closely.

Unlike the more recent developments to establish global governance instruments for investment in agriculture and land tenure, the global governance of forests is far more established. Scholars continue to debate whether a singular international forest regime exists but agree that it consists of multiple public and private institutions and rules, many of which are only loosely interacting in a coordinated manner. An important feature of the global governance of forests is that it contains both international/public and transnational/private instruments, the latter referred to under various labels such as private authority (Cutler et al. 1999), non-state market-driven governance (Cashore 2002), regulatory capitalism (Levi-Faur 2005), and liberal environmentalism (Bernstein 2000). Many forest governance schemes are in fact hybrid forms of governance that involve both public and private actors in policy design and implementation. Private and hybrids forms of forest governance, such as the Forest Stewardship Council (FSC) have eclipsed international forest governance and argued to rank higher in terms of quality and legitimacy than international/public forest governance (Cadman 2011).

The two international/public institutions that are particularly relevant to emergent global land governance are the UN Statement of Forest Principles (UNSFP) and UN Forum on Forests (UNFF). UNSFP is the non-binding international policy framework negotiated by states at the 1992 Rio Summit and is important because the principles established norms around forest governance, namely framing the challenge as deforestation and collapsing forest governance under the framework of sustainable development. ${ }^{\text {vi }}$ The UNFF was established in 2000 and replaced several earlier inter-state forestry governance forums. It is an inter-state body that serves to promote international cooperation on sustainable forest management. Non-state stakeholders are consulted but only states formally participate in decision-making with respect the negotiation of declarations and agreements. Although not a standard-setting body (Cadman 2011), the UN adopted in 2007 the Non-Legally Binding Instrument on All Types of Forest, which is a set of voluntary guidelines to enhance international cooperation on sustainable forest management, monitoring of illegal logging, and action on forest peoples' issues. In addition the instrument established a framework for an international forest financing mechanism to support sustainable forest management and its implementation. 
Reducing Emissions from Deforestation and Forest Degradation (REDD), and now REDD+, is one recent approach to forest conservation that has gained widespread support from states, international organizations and the private sector. REDD+, which is currently under negotiation, is seeking the creation for an international market for carbon credits. How REDD will be designed and governed remains, especially at the national level, remains unclear (Corbera and Schroeder 2011). Yet, if as expected that REDD+ emerges a major pillar of the global environmental regime it may become an important element of emergent global land governance. As REDD+ is unique in its approach of economic incentives as a means to control deforestation and sustainably manage forests it has the potential to link together both exclusion considerations (i.e., livelihoods) and ecological risks (i.e., reducing GHGs emissions/preserving forest carbon stocks). However, it not yet known whether REDD+ will be successful given the low success rate of global environmental instruments reaching their goals (Jabbour et al. 2012). Even if REDD+ is successful with respect to promoting global sustainable forest management in the longer-term, there are significant academic and policy relevant questions related to how such an approach translates to land grabbing beyond that directly related to forests.

\section{Conclusion}

Land governance is now a significant issue in world politics and the subject of new global rulemaking projects. The VGs and ongoing negotiations on responsible agricultural investment signals initial efforts to establish global land governance in response to land grabbing. It also clear that preexisting global governance instruments, such as those related to forestry (and potentially many others), are highly relevant to this emergent global land governance. A central feature of emergent global land governance is that is applicability is not limited to any specific locality, region or country but are targeted worldwide and establish rights and obligations for actors inside and outside the State. In the same instance global land governance is in a state of flux. The constituent elements may alter or expand over time. There is no reason to assume it will develop in a linear manner or that path dependency is evident. Land grabbing may be the contentious political issue today that is driving the debate to a considerable extent but this can change rapidly, for example, if there are major systemic economic or climatic shocks.

Emergent global land governance is unlikely to exhibit the characteristics of a singular, selfcontained international regime. Instead, emergent global land governance has the characteristics associated with much of contemporary governance; land governance is likely to take place through several different types of global governance instruments that are loosely interlinked. This is evident in the three instruments discussed in the preceding section that diverge across issue area (i.e., investment, land tenure, and forestry, respectively), their normative orientation and policy goals (i.e., risk management, land tenure and access to resources, and sustainable forest management, respectively), and the key policy actors involved (i.e., international organizations, agricultural ministries and transnational social movements, and forestry/natural resources ministries, respectively). The potential pool of other global governance instruments - public, private or hybrid - that may be relevant to global land governance is likely to be large given that land issues are highly multidimensional and cut across many different policy fields (e.g., gender, economic development, human rights, etc.). As such, emergent global land governance, as it develops, is likely to be a highly complex and congested domain. The congested and fragmented characteristic of emergent global land governance is significant because this is likely to exacerbate pre-existing and foster new policy challenges and global political contests. This includes political contests between and among states, international organization, private actors and global civil society.

A major challenge posed the congested and fragmented characteristics of emergent global land governance is that there is no agreement about which set(s) of norms will provide the overarching 
framework for global land governance. Such a situation can generate uncertainty for actors about which course of action is most appropriate and also amplify latent political tensions among actors. Thus far, the most influential norms are those from the investment and land tenure fields. These two sets of norms do not hang together well because, in some but not all cases, increasing foreign investment in land may require the weakening of certain forms of land tenure rights such as collective/communal/customary rights. Whereas such tensions are most likely to be solved at the national level on a case-by-case basis, global governance instruments matter precisely because they can inform decisions on the ground by providing actors reference to internationally accepted standards and legal precedents. In addition, global rules alter perceptions about the legitimacy of certain land grabbing practices that can have reputational risks for states and investors alike, for example, if land is acquired through massive dislocation of local people, this could lead to institutionalized practices of naming and shaming and other forms of international condemnation. As such, balancing competing sets of norms in global land governance may require further transnational policymaking and consensus across a highly diverse set of actors with very unequal political and economic resources. This challenge becomes ever more difficult when other normative frameworks are added to the mix such as those found in global environmental governance.

Sustainable development norms, such as those in global forest governance, and securing livelihoods do not always go neatly hand in hand. Conflicts between outsiders wishing to conserve resources and destitute local populations that depend on the exploitation of resources for economic survival raises difficult ethical and social justice dilemmas that must now be increasingly negotiated transnationally and with highly uncertain outcomes for all parties involved. How such tensions and the need to balance competing interests in land use and its governance will shape the future course of global land governance. Therefore, more research on land governance at the global scale is required. So is greater dialogue among land use scientists and global governance scholars to better understand contemporary and future land use challenges and broad-based solutions to them.

\section{Acknowledgements}

I thank two reviewers for their insightful comments on an earlier draft of this chapter and also helpful suggestions from the members of Group 3: Decision Making, Governance and Institutions, Sigrid Quack, Billy Turner and participants of the Ernst Strüngmann Forum: Rethinking Global Land Use in an Urban Era.

\section{References}

Alden Wily, L. 2012. Looking back to see forward: the legal niceties of land theft in land rushes. $J$. Peasant Studies. 39:751-775.

Allan, J.A., M. Keulertz, S. Sojamo and J. Warner. 2012. Handbook of Land and Water Grabs in Africa: Foreign Direct Investment and Food and Water Security. Milon Park and New York: Routledge.

Anseeuw, W., L. Alden-Wily, L. Cotula, and M. Taylor. 2012a. Land rights and the rush for land: Findings of the Global Commercial Pressures on Land Research Project. Rome: ILC.

Anseeuw, W., M. Boche, T. Breu, M. Giger, J. Lay, P. Messerli and K. Nolte. 2012b. Transnational Land Deals for Agriculture in the Global South. Analytical Report based on the Land Matrix Database. Bern/Montpellier/Hamburg: CDE/CIRAD/GIGA.

Auld, G. 2013. Private market-based regulations: What they are, and what they mean for land-use governance. In: Rethinking Global Land Use in an Urban Era, eds. K.C. Seto and A. Reenberg. Strüngmann Forum Reports Vol. 14. Cambridge, MA: MIT Press.

Ayers, A.J. 2012. Beyond myths, lies and stereotypes: The political economy of a 'New Scramble for Africa. New Political Economy. In press. 
Bernstein, S. 2000. Ideas, social structure and the compromise of liberal environmentalism. European J. International Relations. 6:464-512.

Borras, S.M., J.C. Franco, and C. Wang, C. 2013a. The challenge of global governance of land grabbing: Changing international agricultural context and competing political views and strategies. Globalizations. 10. In press.

Borras, S.M., S. Gomez, C. Kay and J. Wilkinson. 2013b. Land grabbing and global capitalist accumulation: Key features in Latin America. Can. J. Development Studies. 33:2-16.

Borras, S.M. et al. 2013c. New actors and political agency in global land use change: Political interactions and the variable outcomes of large-scale land acquisitions. In: Rethinking Global Land Use in an Urban Era, eds. K.C. Seto and A. Reenberg. Strüngmann Forum Reports Vol. 14. Cambridge, MA: MIT Press.

Borras, S.M., J.C. Franco, S. Gómez, C. Kay and M. Spoor. 2012. Land grabbing in Latin America and the Caribbean. J. Peasant Studies. 39: 845-872.

Borras, S.M., R. Hall, I. Scoones, B. White, W. Wolford. 2011. Towards a better understanding of global land grabbing: an editorial introduction. J. Peasant Studies. 38: 209-216.

Borras, S.M., P.D. McMichael, and I. Scoones. 2010. The politics of biofuels, land and agrarian change: editors' introduction. J. Peasant Studies. 37:

Cadman, T. 2011. Quality and Legitimacy of Global Governance: Case Lessons from Forestry. Basingstoke, Hampshire, UK: Palgrave McMillan.

Cashore, B. 2002. Legitimacy and the privatization of environmental governance: How non-state market-driven (NSMD) governance systems gain rule-making authority. Governance. 15:503-529.

Corbera, E. and H. Schroeder, H. 2011. Governing and implementing REDD+. Environmental Science and Policy, 14:89-99.

Cotula, L. 2012. The international political economy of the global land rush: A critical appraisal of trends, scale, geography and drivers. J. Peasant Studies. 39: 649-680.

Cotula, L. 2011. Land deals in Africa: What is in the contracts? London: International Institute for Environment and Development.

Cotula, L., S. Vermeulen, R. Leonard and J. Keeley. 2009. Land grab or development opportunity? Agricultural investment and international land deals in Africa. London: International Institute for Environment and Development.

Cutler, A.C., V., and T. Porter. 1999. Private Authority and International Affairs. Albany, NY: SUNY Press.

Deininger, K., D. Byerlee, J. Lindsay, A. Norton, H. Selod and M. Stickler. 2011.

Rising global interest in farmland: Can it yield sustainable and equitable benefits? (Washington, DC: World Bank).

Fairhead, J., M. Leach, and I. Scoones. 2012. Green grabbing: a new appropriation of nature? J. Peasant Studies. 39:237-261.

Filer, C. 2012. Why green grabs don't work in Papua New Guinea. Journal. Peasant Studies 39:599-617.

Friis, C. and A. Reenberg. 2010. Land grab in Africa: Emerging land system drivers in a teleconnected world. GLP Report No. 1. Copenhagen: GLP-IPO.

Fan, S. and A. Ramirez, 2012. Achieving food security while switching to low carbon agriculture. J. Renewable Sustainable Energy 4.

Food and Agriculture Organization of the United Nations (FAO). 1979. Declaration of principles of the World Conference on Agrarian Reform and Rural Development. Rome: FAO.

FAO. 2010. Zero Draft/Voluntary Guidelines on the Responsible Governance of Tenure of Land and Other Natural Resources. Rome: FAO.

FAO. 2012. Voluntary Guidelines on the Responsible Governance of Tenure of Land, Fisheries and Forests in the Context of National Food Security. Rome: FAO.

Graham, A., S. Aubry, R. Künnemann, and S. Monsalve Suárez. 2010. Land Grab Study. Heidelberg: FIAN. 
Gentry, B.S. et al. 2013. Changes in land governance in an urban era. In: Rethinking Global Land Use in an Urban Era, eds. K.C. Seto and A. Reenberg. Strüngmann Forum Reports Vol. 14. Cambridge, MA: MIT Press.

GRAIN 2008. GRAIN. 2008. Seized! The 2008 land grab for food and financial security. Grain Briefing. Barcelona: GRAIN.

GTZ. 2009. Foreign direct investment (FDI) in land in developing countries. Echbern: Ministry of Economic Cooperation and Development.

Hall, D. 2011. Land grabs, land control, and Southeast Asian crop booms. J. Peasant Studies. 38: 837-857.

Jabbour, J., F. Keita-Ouane, C. Hunsberger, R. Sanchez-Rodriguez, P., N. Patel, A. Singh, M.A. Levy and S.. 2012. Internationally agreed environmental goals: A critical evaluation of progress. Environmental Development 3:5-24.

Jones, P.S. 2011. Powering up the people? The politics of indigenous rights implementation: International Labour Organisation Convention 169 and hydroelectric power in Nepal. The Intl. J. of Human Rights 16:624-647.

Levi-Faur, D. 2005. The global diffusion of regulatory capitalism. Annals American Academy of Political and Social Science. 598:12-32.

Liu, J. and V. Hall. 2013. Telecouplings and global land use. In: Rethinking Global Land Use in an Urban Era, eds. K.C. Seto and A. Reenberg. Strüngmann Forum Reports Vol. 14. Cambridge, MA: MIT Press.

Margulis, M.E. \& T. Porter. 2013. Governing the global land grab: Multipolarity, ideas and complexity in transnational governance. Globalizations. 10. In press.

Margulis, M.E., N. McKeon and S.M. Borras. 2013. Land grabbing and global governance: Critical perspectives. Globalizations. 10. In press.

Mehta, L., G.J. Veldwisch and J.C. Franco. 2012. Introduction to the special issue: Water grabbing? Focus on the (re)appropriation of finite water resources. Water Alternatives 5:193-207.

Niasse, M. 2011. Access to land and water for the rural poor in a context of growing resource scarcity. Paper presented at the IFAD Conference on New Directions for Smallholder Agriculture 24-25 January, 2011. Rome: IFAD.

Nelson, G.C., M.W. Rosegrant, A. Palazzo, I. Gray, C. Ingersoll, R. Robertson, S. Tokgoz,

T. Zhu, T. B. Sulser, C. Ringler, S. Msangi and L. You. 2010. Food security, farming, and climate change to 2050: scenarios, results, policy options. Washington, D.C.: IFPRI.

Norgaard, R.B. 2010. Ecosystem services: From eye-opening metaphor to complexity blinder. Ecological Economics 69:1219-1227.

Oxfam. 2012. Land and power: The growing scandal surrounding the new wave of investments in land. http://www.oxfam.org/sites/www.oxfam.org/files/bp151-land-power-rightsacquisitions-220911-en.pdf.

Raustalia, K. and D. G. Victor. 2004. The regime complex for plant genetic resources. International Organization 58:277-309.

Rosenau, J.N. 1995. Governance in the Twenty-first Century. Global Governance. 6:13-43.

Rulli, M.C., A. Saviori and P. D'Odorico. 2013. Global land and water grabbing. Proceedings of the National Academy of Sciences. Online first.

Sassen, S. 2013. Land grabs today: Feeding the disassembling of national territory. Globalizations. 10. In press.

Seto, K.C. and A Reenberg. 2013. Rethinking global land use in an urban era: An introduction. In: Rethinking Global Land Use in an Urban Era, eds. K.C. Seto and A. Reenberg. Strüngmann Forum Reports Vol. 14. Cambridge, MA: MIT Press.

Seufert, P. 2013. Voluntary Guidelines on the Responsible Governance of Tenure of Land, Fisheries and Forests. Globalizations. 10. In press.

Smith, J. 2007. Social Movements for Global Democracy. Baltimore, ML: John Hopkins University Press. 
Turner, B. L., E. F. Lambin and A. Reenberg. 2007. The emergence of land change science for global environmental change and sustainability. Proceedings of the National Academy of Sciences 104:20666-20671.

van der Horst, D. and S. Vermeylen. 2011. Spatial scale and social impacts of biofuel production. Biomass and Bioenergy 35:2435-2443.

Visser, O. and M. Spoor. 2012. Land grabbing in post-Soviet Eurasia: the world's largest agricultural land reserves at stake. J. Peasant Studies. 38: 299-323.

Wicke, B. 2013. Distal land connections: Palm oil as a case study. In: Rethinking Global Land Use in an Urban Era, eds. K.C. Seto and A. Reenberg. Strüngmann Forum Reports Vol. 14. Cambridge, MA: MIT Press.

World Bank. 2009. Large-scale acquisition of land rights for agricultural or natural resource-based use. Washington: World Bank.

Xanthaki, A. 2010. Xanthaki, Alexandra. Indigenous rights in international law over the last 10 years and future developments. Melb. J. Int'l L. 10.

Young, O. 2002. The Institutional Dimensions of Environmental Change: Fit, Interplay, and Scale. Cambridge, MA: MIT Press.

Zoomers, A. 2010. Globalisation and the foreignisation of space: Seven processes driving the current global land grab. J. Peasant Studies. 37:429-447.

\footnotetext{
${ }^{\mathrm{i}}$ For example, this is evident in the formal participation of global civil society organizations and increasingly private sector actors in policy deliberations at the Committee for World Food Security.

ii Obtaining reliable data on land grabs remain a significant challenge because of the lack of transparency. In order to provide an empirical basis for this argument Table 1 uses data obtained from the recent Land Matrix project as an indicator of land grabbing activity. Table 1 only displays verified land deals in a given year and it is important to note that the Land Matrix claims at least 44 million hectares of land grabs remain in the process of verification.

iii These categories of concerns overlap with concerns about land grabs at the local and national level but play out differently in these contexts.

iv Group of Eight (G-8), “Responsible Leadership for a Sustainable Future,” Declaration of the L'Aquila Summit, July 8, 2009: 113(b).

v The full text of the draft PRAI is available at: http://siteresources.worldbank.org/INTARD/2145741111138388661/22453321/Principles_Extended.pdf.

${ }^{v i}$ This normative orientation diverges significantly from other international instruments in forestry such as the International Tropical Timber Agreement (ITTA) that initially sought to stabilize timber prices and supply through direct cooperation among major producers and consumers.
} 